\title{
Genetic Diversity Estimates for the Genus Hydrangea and Development of a Molecular Key Based on SSR
}

\author{
Timothy A. Rinehart \\ USDA-ARS, Southern Horticultural Laboratory, 810 Highway 26 West, Poplarville, MS 39470
}

Brian E. Scheffler

USDA-ARS-CGRU, Mid South Area Genomics Laboratory, Stoneville, MS 38776

\author{
Sandra M. Reed \\ USDA-ARS, Floral and Nursery Plants Research Unit, Tennessee State University Nursery Research \\ Center, McMinnville, TN 37110
}

\begin{abstract}
AdDitIONAL INDEX wORDs. Hydrangea macrophylla breeding, molecular marker, Dichroa, Schizophragma, Platycrater
Abstract. Using 14 codominant microsatellite markers that amplify loci across 14 different Hydrangea L. species, we analyzed gene diversity and genetic similarity within Hydrangea. Samples also included Dichroa Lour., Platycrater Sieb. and Zucc., and Schizophragma Sieb. and Zucc. genera to establish their relatedness to Hydrangea species since previous work suggests they may be closely related. Our results support the close affiliation between Macrophyllae E.M. McClint. and Petalanthe (Maxim.) Rehder subsections and their separation from the other Hydrangea species. Most of the Hydrangea species analyzed cluster within their designated sections and subsections; however, genetic distance between species within each subsection varied considerably. Our data suggest that morphological analyses which labeled H. serrata (Thunb.) Ser. as a subspecies of H. macrophylla (Thunb. Ex J.A. Murr.) Ser. are probably more accurate than recent genome size data suggesting $H$. macrophylla ssp. macrophylla (Thunb.) Ser. and $H$. macrophylla ssp. serrata (Thunb.) Makino are separate species. Gene diversity estimates indicate that $64.7 \%$ of the total diversity is due to differences between species and $49.7 \%$ of the overall variation is due to differences between subsections. Low diversity suggests a lack of gene flow between species and subsections and underscores the difficulty in making wide hybrids. Since only $35.3 \%$ of the genetic variation is common to all species, unique alleles were used to develop a molecular key for unambiguous species identification and interspecific hybrid verification. Genetic similarity estimates for all 85 samples suggests a roadmap for introgressing horticulturally important traits from different Hydrangea species.
\end{abstract}

Hydrangeas are the fourth top selling deciduous flowering shrub in the United States with annual sales in excess of \$32 million. Hydrangea macrophylla is the most popular species, but four other members of the genus are cultivated in this country. While most of the H. macrophylla cultivars available today were developed in Europe during the first half of the 20th century, there are currently breeding efforts under way targeted at developing reliable, low-maintenance $H$. macrophylla with a wide array of desirable ornamental traits. Breeding efforts are also under way to improve $H$. quercifolia Bartr., H. paniculata Sieb., and $H$. arborescens L. Despite a recent increase in hydrangea breeding and interest in germplasm conservation, relatively little is known about the relatedness between Hydrangea species. The last major revision of Hydrangea taxonomy was carried out in 1957 by McClintock, who established the species designations commonly used today.

In an effort to accelerate breeding of new cultivars, we established simple sequence repeat (SSR) markers for Hydrangea.

Received for publication 9 May 2006. Accepted for publication 29 June 2006. David Creech and Barbara Stump at the Mast Arboretum at Stephen F. Austin State Univ. in Nacogdoches, TX, and Kristin VanHoose at Bell Family Nursery in Aurora, Ore., graciously donated tissue and plants from their collections for this research. We are especially thankful for the efforts of Yonmee Han in generating data and the Mid South Area Genomics lab (Linda Ballard, Mary Duke, Xiaofen Liu, and Sheron Simpson) for their technical expertise. Keri Jones provided valuable insight into the genome sizes for Hydrangea and related species. Mention of trade names or commercial products in this article is solely for the purpose of providing specific information and does not imply recommendation or endorsement by the U.S. Dept. of Agriculture.
During development of a marker-assisted breeding program for $H$. macrophylla, we discovered 14 microsatellite loci that amplify across Hydrangea species. Here we used these SSR loci to better understand the relationships within Hydrangea species and between Hydrangea and related genera that may represent alternative sources of genetic diversity for hydrangea breeding programs (Fan and Xiang, 2003).

Hydrangeoideae is a subfamily of the Hydrangeaceae and includes two tribes, Cardiandreae with two genera and Hydrangeae with nine genera including at least six horticulturally important Hydrangea species. While the tribe Hydrangeae is considered monophyletic, seven of the genera in Hydrangeae are proposed to be polyphyletic including Broussaisia Gaudich., Decumaria L., Dichroa, Hydrangea, Pileostegia Hook. f., and Thomson, Platycrater, and Schizophragma. Two other genera, Cardiandra Sieb. and Zucc. and Deinanthe Maxim., are considered basal. Phylogenetic work using DNA sequence data from rbcL and matK loci and morphological characters supports four clades within the polyphyletic group (Fig. 1) but relationships between other species remain unresolved (Hufford, 1995, 1997, 2001; Hufford et al., 2001).

McClintock (1957) successfully organized Hydrangea into 23 species, largely by avoiding pubescence characters and carefully mapping their disjunct geographic distributions. She developed a morphological key to identify species and divided the genus into two sections, Hydrangea Maxim. and Cornidia (Ruiz and Pavon) Engler, which contain six and two subsections respectively (Table 1). Her taxonomic designations are generally supported by recent 


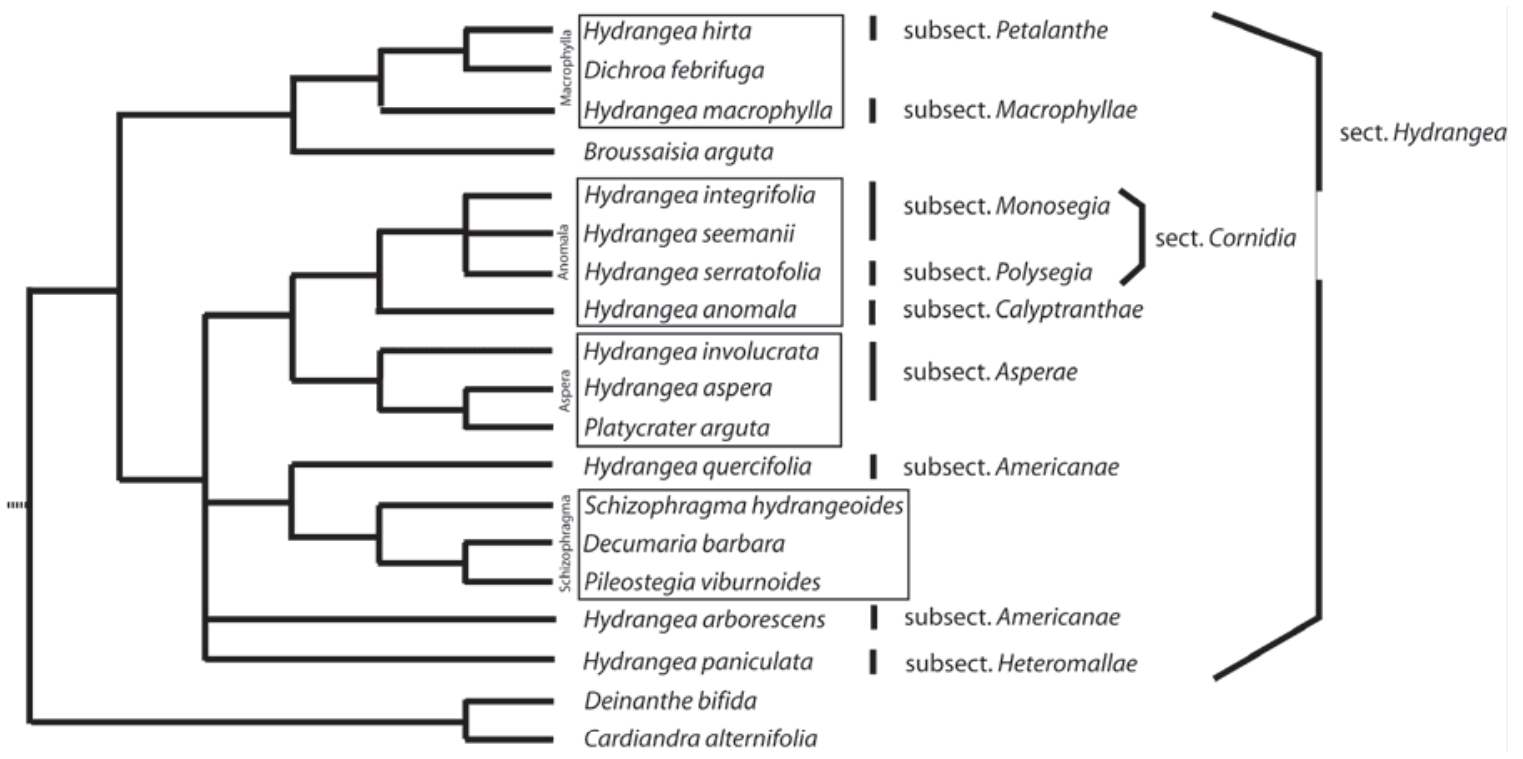

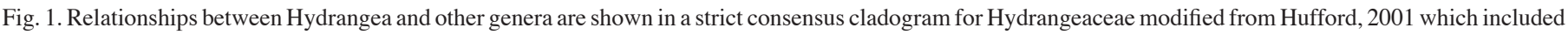
DNA sequence data from rBCL genes. Clades are boxed. Sections (sect.) and subsections (subsect.) are shown to the right of the dendogram.

research and are accepted as the current standard (Hufford, 2001). However, there are several controversies that can be addressed with the SSR data presented here.

First, the taxonomic treatment of Hydrangea subsection Macrophyllae has long been disputed. Hydrangea macrophylla ssp. macrophylla and $H$. macrophylla ssp. serrata were initially considered to be closely related species (Wilson, 1923), but were combined into a single species by Makino (Hara, 1955). HaworthBooth (1984) recommended dividing the subsection into four species. He believed that $H$. macrophylla was a complex hybrid $(\times H$. macrophylla) produced from hybridizations of a coastal species (H. maritima Sieb. and Zucc.), with three woodland species (H. acuminata Sieb. and Zucc., H. japonica Sieb. and Zucc. and H. thunbergii Sieb.). Because the traits that Haworth-Booth ascribed to the four species were primarily ecological and cultural responses, McClintock (1957) did not support his reclassification of the subsection or a hybrid origin for H. macrophylla. While she kept serrata at the subspecies level, recent publications by several leading authorities on Hydrangea have reverted back to the species designation (Dirr, 2004; Mallet, 1994; Lawson-Hall and Rothera, 1995; van Gelderen and van Gelderen, 2004). Most of the argument supporting separation of H. macrophylla ssp. macrophylla and H. macrophylla ssp. serrata is based on morphological and geographical distribution differences between the two groups; however, molecular data has recently been presented in support of elevation of serrata to species status. Flow cytometric measurements of propidium iodide stained nuclei revealed that, although both sets of plants had the same chromosome number, the mean nuclear DNA content of 16 macrophylla cultivars was $5.8 \%$ greater than that of 18 serrata cultivars (Zonneveld, 2004). Although DNA content has limited phylogenetic usefulness (Cerbah et al., 2001), it has been used to characterize species, verify triploid cultivars, and uncover interspecific hybrids within Hydrangea (Demilly et al., 2000; Zonneveld, 2004).

Second, the genetic distance between Macrophyllae and Petalanthe and the other subsections has not been determined, nor has it been resolved for the four other subsections that originate in eastern Asia. The relationship between $H$. quercifolia and $H$. arborescens in subsection Americanae (Maxim.) Engler is also relatively unresolved since they appear distantly related despite being native to overlapping geographic regions.

Finally, relationships between various species of Hydrangea and members of related genera have been proposed but are not fully understood. Dichroa is supposedly related to H. macrophylla but its relationship within Macrophyllae is not well defined (Hufford, 2001). Schizophragma is sometimes allied with subsection Americanae and sometimes subsection Heteromallae Rehder (Hufford, 2001; Hufford et al., 2001). Platycrater is thought to be similar to subsection Asperae Rehder.

In addition to clarifying relationships between species, gene diversity estimates and genetic similarity clustering will be important information for choosing parents for wide hybridization studies. There has been difficulty in creating wide hybrids in Hydrangea, which may be due in part to differences in genome size and chromosome number between parents. Hydrangea arborescens, which has a small genome [2.64 pg DNA per diploid nucleus (2C)] and $2 \mathrm{n}=38$ chromosomes, has been successfully crossed with Hydrangea involucrata Sieb., which has fewer chromosomes $(2 n=30)$ but a larger genome $(5.36 \mathrm{pg} / 2 \mathrm{C})($ Cerbah et al., 2001; Jones and Reed, 2006). Embryo rescue was used to produce hybrids between $H$. macrophylla and $H$. quercifolia, $H$. arborescens and $H$. paniculata, but all three hybrids were weak, aneuploid and/or sterile (Kudo et al., 2002; Kudo and Niimi, 1999; Reed, 2004; Reed et al., 2001). Hydrangea quercifolia has the smallest known genome size $(2.17 \mathrm{pg} / 2 \mathrm{c})$ and has $2 \mathrm{n}=$ 36 chromosomes (Cerbah et al., 2001; Zonneveld, 2004). The genome size for $H$. paniculata is the largest of the Hydrangea species examined at $7.00 \mathrm{pg} / 2 \mathrm{C}$ (Cerbah et al., 2001; Zonneveld, 2004), but it is a tetraploid with $2 \mathrm{n}=72$ chromosomes (Sax, 1931). The only Hydrangea interspecific hybrid to be introduced into the trade is a hybrid between $H$. aspera $\mathrm{D}$. Don and $H$. involucrata (Dirr, 2004), which are in the same subsection.

Genome size does not necessarily coordinate with chromosome number or fertility. Cerbah estimates $2 \mathrm{n}=36$ for $H$. macrophylla cultivars but some triploid cultivars have been identified (Cerbah et al., 2001; Demilly et al., 2000; Zonneveld, 2004). Interestingly, both ploidy types appear fertile (K. Jones, personal communication). Hydrangea macrophylla ssp. serrata has $2 \mathrm{n}=36$ 
Table 1. Overview of the Hydrangea genus including infrageneric divisions, geographic origin, and common synonyms for taxa.

\begin{tabular}{|c|c|c|c|c|c|}
\hline Section & Subsection & Species & Subspecies & Native habitat & Possible synonyms \\
\hline Hydrangea & $\begin{array}{l}\text { Americanae } \\
\text { (Maxim.) }\end{array}$ & & & & \\
\hline \multirow[t]{31}{*}{ Maxim. } & Engler & H. arborescens $\mathrm{L}$. & arborescens $\mathrm{L}^{\mathrm{z}}$ & Eastern U.S. & \\
\hline & & & $\begin{array}{l}\text { radiata (Walter) E.M. McClint. } \\
\text { discolor (Ser. ex DC.) E.M. } \\
\text { McClint. }^{\mathrm{z}}\end{array}$ & & \\
\hline & & H. quercifolia W. Bartram ${ }^{\mathrm{z}}$ & & Eastern U.S. & \\
\hline & Asperae & & & & \\
\hline & Rehder & H. sikokiana Maxim. $^{\mathrm{z}}$ & & Eastern Asia & \\
\hline & & H. involucrata Sieb. ${ }^{\mathrm{z}}$ & & Eastern Asia & \\
\hline & & H. aspera Buch.-Ham. ex & & & \\
\hline & & D. Don & aspera Buch.-Ham. ex D. Don ${ }^{z}$ & Eastern Asia & \\
\hline & & & strigosa (Rehder) E.M. McClint. ${ }^{\mathrm{z}}$ & & \\
\hline & & & robusta (Hook. f. and Thomson) & & \\
\hline & & & $\begin{array}{l}\text { E.M. McClint. } \\
\text { sargentiana (Rehder) E.M. }\end{array}$ & & \\
\hline & & & $\begin{array}{l}\text { Sargentiana (Render) E.M. } \\
\text { McClint. }^{z}\end{array}$ & & H. sargentiana \\
\hline & & & villosa Rehder $^{2}$ & & H. villosa \\
\hline & $\begin{array}{l}\text { Calyptranthae } \\
\text { (Maxim.) E.M. }\end{array}$ & & & & \\
\hline & McClint. & H. anomala D. Don & anomala D. Don ${ }^{2}$ & Eastern Asia & \\
\hline & & & $\begin{array}{l}\text { petiolaris (Sieb. and Zucc.) E.M. } \\
\text { McClint. }^{\mathrm{z}}\end{array}$ & & $\begin{array}{l}\text { H. petiolaris, } \\
\text { H. quelpartensis }\end{array}$ \\
\hline & $\begin{array}{l}\text { Petalanthe } \\
\text { (Maxim.) }\end{array}$ & & & & \\
\hline & Rehder & H. hirta (Thunb.) Sieb. & & Eastern Asia & \\
\hline & & H. scandens (L. f.) Ser. & scandens (L. f.) Ser. & Eastern Asia & \\
\hline & & & liukiuensis (Nakai) E.M. McClint. ${ }^{\mathrm{Z}}$ & & $\begin{array}{l}\text { H. luteovenosa } \\
\text { H. angustipetala, }\end{array}$ \\
\hline & & & chinensis (Maxim.) E.M. McClint. ${ }^{\mathrm{z}}$ & & H. lobbii \\
\hline & & & kwangtungensis Merr. & & \\
\hline & Heteromallae & & & & \\
\hline & Rehder & H. paniculata Sieb. ${ }^{\mathrm{z}}$ & & Eastern Asia & \\
\hline & & H. heteromalla D. Don ${ }^{z}$ & & Eastern Asia & H. xanthoneura \\
\hline & Macrophyllae & H. macrophylla (Thunb.) & & & \\
\hline & E.M. McClint. & Ser. & macrophylla (Thunb.) Ser. ${ }^{\mathrm{z}}$ & Eastern Asia & \\
\hline & & & serrata (Thunb.) Makino ${ }^{z}$ & & H. serrata \\
\hline & & & stylosa (Hook. f. and Thomson) & & \\
\hline & & & E.M. McClint. & & \\
\hline & & & chungii (Rehder) E.M. McClint. & & \\
\hline \multirow{19}{*}{$\begin{array}{l}\text { Cornidia (Ruiz } \\
\text { and Pavon) } \\
\text { Engler }\end{array}$} & Monosegia & & & & \\
\hline & Briq. & H. seemannii Riley $^{z}$ & & Mexico & \\
\hline & & & & Central and South & \\
\hline & & H. asterolasia Diels & & America & \\
\hline & & & & Phillipines and & \\
\hline & & H. integrifolia Hayata $^{\mathrm{z}}$ & & Formosa & \\
\hline & & & & Central and South & \\
\hline & & H. oerstedii Briq. & & America & \\
\hline & & & & Central and South & \\
\hline & & H. peruviana Moric. ex Ser. & & America & \\
\hline & & H. diplostermona Standl. & & Central America & \\
\hline & & & & Central and South & \\
\hline & & H. preslii Briq. & & America & \\
\hline & & H. steyermarkii Standl. & & Central America & \\
\hline & & H. serratifolia (Hook. and & & & \\
\hline & Polysegia Briq. & Arn.) F. Phil. ${ }^{z}$ & & South America & \\
\hline & & H. tarapotensis Briq. & & South America & \\
\hline & & H. jelskii Zahlbr. & & South America & \\
\hline & & H. mathewsii Briq. & & South America & \\
\hline
\end{tabular}

Indicates taxa that were included in this study.

chromosomes, the same number as diploid $H$. macrophylla ssp. macrophylla, despite the fact that the average genome size for H. macrophylla ssp. serrata is $4.29 \mathrm{pg} / 2 \mathrm{C}$, slightly less than 4.54 $\mathrm{pg} / 2 \mathrm{C}$ estimated for H. macrophylla ssp. macrophylla (Zonneveld, 2004). Additionally, chromosome counts indicate $2 n=36$ for
H. aspera ssp. aspera Buch.-Ham. ex D. Don but $2 \mathrm{n}=34$ for H. aspera ssp. robusta (Hook. f. and Thompson) E.M. McClint. and $H$. aspera ssp. sargentiana (Rehder) E.M. McClint. Genome sizes for these taxa are $3.5,3.5$, and $3.36 \mathrm{pg} / 2 \mathrm{C}$, respectively (Zonneveld, 2004). 
The objective of this research was to use SSR markers to study relationships within Hydrangea and between Hydrangea and related genera. Codominant locus-specific markers such as SSR should provide relatively unbiased genetic distance estimates within and between subsections. Data presented here demonstrate the usefulness of SSR loci for species identification, germplasm conservation, and offer insight into future hydrangea breeding, particularly the creation of wide hybrids were relatively little progress has been made.

\section{Materials and Methods}

SSR DEVELOPMENT. Four SSR-enriched libraries, each containing $\approx 15,000$ recombinant cells, were made from genomic DNA of $H$. macrophylla and $H$. paniculata (Genetic Information Services, Chatsworth, Calif.). From these libraries, 1152 random clones were sequenced and analyzed and 670 potential SSR primer pairs with an average repeat number of 11 were identified. Of these, 288 primer pairs were tested against a panel of 12 DNAs representing eight Hydrangea species. Fourteen loci produced polymorphic data for all samples tested suggesting they would amplify in all species within the genus (Table 1).

SAMPLing STRATEgY. Wildtype plants are not readily available for taxa listed in Table 1, particularly H. macrophylla, which have been subjected to prolonged cultivation. Tissue samples were collected from multiple sources for most taxa to guard against plant mislabeling. However, Platycrater arguta Sieb. et Zucc. and Hydrangea sikokiana Maxim. are each represented by only a single sample. As many cultivars as possible were sampled for each species resulting in uneven numbers of samples between species. The popularity of H. macrophylla was offset by choosing cultivars from different breeding programs to cover as much of the diversity as possible. We also included several remontant $H$. macrophylla cultivars that are economically important since our emphasis is on hydrangea breeding. For the sake of clarity, $H$. macrophylla ssp. macrophylla cultivars are listed as H. macrophylla and $H$. macrophylla ssp. serrata cultivars are listed as $H$. serrata in figures. The two other H. macrophylla subspecies, ssp. stylosa (Hook. f. and Thomson) E.M. McClint. and ssp. chungii (Rehder) E.M. McClint., are not represented in this study. Uneven sample sizes and deviations from Hardy-Weinburg equilibrium due to selection did not alter phenetic comparisons, which are based on genetic distance estimates.

SAMPle Processing. DNA was extracted from $1 \times 1-\mathrm{cm}$ pieces of fresh leaf tissue using Qiagen Plant Mini Kit (Qiagen, Valencia, Calif.), quantified using a NanoDrop Spectrophotometer (Nanodrop Technologies, Wilmington, Del.), and diluted to a final concentration of $5 \mathrm{ng} \cdot \mu \mathrm{L}^{-1}$. Amplification was performed using a 3-primer protocol modified from (Waldbieser et al., 2003). Oligonucleotides corresponding to the forward primers listed in Table 2 were synthesized with 18 nucleotides added to the 5' end (5' CAGTTTTCCCAGTCACGA $3^{\prime}$ ) and were included in PCR reactions at final concentrations of $0.4 \mu \mathrm{M}$. Reverse primers included the addition of $5^{\prime}$ GTTT $3^{\prime}$ at the $5^{\prime}$ end and were included in PCR reactions at final concentrations of $1.8 \mu \mathrm{M}$. Reaction volumes were $10 \mu \mathrm{L}$ and included $30 \mathrm{ng}$ of genomic DNA along with $0.3 \mu \mathrm{L}$ Advantage 2 polymerase mix (Clontech, Mountain View, Calif.), $0.2 \mu \mathrm{L}$ Ultrapure dNTPs (Clontech), 1.0 $\mu \mathrm{L}$ Advantage2 PCR buffer (Clontech) and a third primer (5' CAGTTTTCCCAGTCACGAC 3') fluorescently labeled with FAM at a final concentration of $0.75 \mu \mathrm{M}$. PCR conditions included 3 minutes at $95^{\circ} \mathrm{C}, 2$ cycles of $95^{\circ} \mathrm{C}$ for 1 min then $60^{\circ} \mathrm{C}$ for 1 min, then 27 cycles of $95^{\circ} \mathrm{C}$ for $30 \mathrm{~s}, 60^{\circ} \mathrm{C}$ for $30 \mathrm{~s}$, and $68^{\circ} \mathrm{C}$ for $30 \mathrm{~s}$. Cycling was finished after $68^{\circ} \mathrm{C}$ soak for $4 \mathrm{~min}$ followed by storage at $4{ }^{\circ} \mathrm{C}$. All cycling was carried out in 96 -well plates using a Tetrad thermocycler (Bio-Rad Laboratories, Waltham, Mass.). Fluorescence-labeled PCR fragments were visualized by automated capillary gel electrophoresis on an ABI3100-Avant or

Table 2. SSR loci that were selected from a Hydrangea DNA library. Locus names correspond to SSR-enriched clones. Expected allele sizes were calculated based on the H. macrophylla DNA sequences which can be found by querying the National Institutes of Health genetic sequence database (GenBank) using the accession number listed.

\begin{tabular}{|c|c|c|c|c|c|c|}
\hline Locus & $\begin{array}{c}\text { GenBank } \\
\text { accession } \\
\text { no. }\end{array}$ & $\begin{array}{c}\text { Repeat } \\
\text { motif }\end{array}$ & $\begin{array}{c}\text { Expected } \\
\text { allele size } \\
\text { (bp) }\end{array}$ & $\begin{array}{l}\text { Actual allele } \\
\text { size range } \\
\text { (bp) }\end{array}$ & Forward primer & Reverse primer \\
\hline STAB045_046 & DQ521440 & (TCA) 8 & 151 & $153-174$ & AGAGGTCAGGCCTTGGAAAGATAC & AGAGGTCAGGCCTTGGAAAGATAC \\
\hline STAB061_062 & DQ521439 & $(\mathrm{CAC}) 4$ & 96 & $96-119$ & CGGATCCAAAACCCTAATACAACA & ATAATGGAGGAGACGGAGAGTGTG \\
\hline STAB111_112 & DQ521451 & (TCG)6 & 160 & $154-190$ & СTTCTTCCTCTTCTTTGGTGGTTG & AGAGAATGGAGATGACGACGATG \\
\hline STAB125_126 & DQ521450 & $(\mathrm{CTT}) 4$ & 136 & $154-181$ & CAGTATCTCTGCCCAATCGAGAAT & TGACCAGAACGATGAGAATGAAAA \\
\hline STAB157_158 & DQ521449 & $(\mathrm{GCA}) 10$ & 150 & $149-179$ & TCCATCGAGTTCAACTTCTTCTCC & AGTCGCAGATCTCACTTATTTCGG \\
\hline STAB285_286 & DQ521448 & $(\mathrm{CTG}) 8$ & 159 & $159-183$ & CAGCCACCACTGCTACTGCTACTA & GATCCACCATTTTAGTGATTCGGA \\
\hline STAB307_308 & DQ521447 & (TGG)4 & 109 & $108-132$ & GGGTTTATGGGCAGATGAATTTT & AAATTACCAATTTGCCCCATCTG \\
\hline STAB309_310 & DQ521447 & $(\mathrm{GCC}) 4$ & 104 & $116-126$ & GGGCAAAATGGTAACCTTCCTATG & TGAAAAGTAATGCCTACCGATGCT \\
\hline STAB311_312 & DQ521446 & $(\mathrm{CCA}) 5$ & 141 & $116-187$ & AGTGCCAGCATCACCACTAACATA & AACTATGGAAGTGGAGGCGGTTAT \\
\hline STAB321_322 & DQ521444 & (TCT) 7 & 159 & $164-185$ & CTAACAATTTCACCCATTTGAGGC & ATTAGGACTTACAGTCGCCGAGC \\
\hline STAB391_392 & DQ521443 & (TCA) 7 & 145 & $158-176$ & CCAACССТTTCCTAAACTGCTCTT & AAGGGTGTGTTTGAGGATGTTGAT \\
\hline STAB429_430 & DQ521442 & (CTG)6 & 83 & $84-103$ & GCTGGGATTGATTGTTGTACCC & ATGAGTAGCAGCAGAGGAGGAAGA \\
\hline STAB457_458 & DQ521441 & (TTC) 4 & 160 & $166-181$ & CAGGTGATGGAGATGGGGATATAG & TTGCAGTTGGAACTGATCAGAGAG \\
\hline STAB501_502 & DQ521445 & $(\mathrm{CAA}) 4$ & 118 & 115-194 & CATTTTGGTGGGTGGTTTAGGATA & TGTTGTTGCTGCTGTATTTGTGAA \\
\hline
\end{tabular}


Table 3. Source and cultivar information for Hydrangea, Dichroa, Platycrater and Schizophragma samples used in this study. Group designations were used to indicate plants labeled with synonyms. Accession numbers correspond to individual plants in research and display collections.

\begin{tabular}{|c|c|}
\hline Taxa & Source $^{\mathrm{z}}$ (accession no.) \\
\hline H. arborescens 'Annabelle' & S. Reed (G156A) \\
\hline H. arborescens ssp. discolor 'Frosty' & S. Reed (G665A) \\
\hline H. arborescens ssp. radiata 'WhiteDome' & S. Reed (G671A) \\
\hline H. quercifolia 'Alice' & Bell Family Nursery \\
\hline H. quercifolia 'Pee Wee' & S. Reed (G688C) \\
\hline H. quercifolia 'Semmes Select' & MAST (54603) \\
\hline H. quercifolia 'Snowflake' & MAST (40201) \\
\hline H. quercifolia 'SnowQueen' & Bell Family Nursery \\
\hline H. sikokiana & M. Dirr \\
\hline H. involucrata 1 & MAST (45500) \\
\hline H. involucrata 2 & S. Reed (G331A) \\
\hline H. involucrata 'Plena' & MAST (3405) \\
\hline H. involucrata 'Tama Azisai' & Bell Family Nursery \\
\hline H. aspera & S. Reed (G628A) \\
\hline H. aspera 'Rocklon' & MAST (13101) \\
\hline H. aspera 'NCSU' & MAST (72800) \\
\hline H. aspera ssp. robusta & S. Reed (G629A) \\
\hline H. aspera ssp. sargentiana & MAST (44900) \\
\hline H. aspera ssp. sargentiana 'Sargent' & Bell Family Nursery \\
\hline H. aspera ssp. strigosa & S. Reed (G630A) \\
\hline H. aspera ssp. villosa 1 & MAST (45100) \\
\hline H. aspera ssp. villosa 2 & MAST (45100) \\
\hline H. aspera ssp. villosa 3 & Bell Family Nursery \\
\hline H. anomala ssp. petiolaris $1^{\mathrm{y}}$ & S. Reed (G132A) \\
\hline H. anomala ssp. petiolaris 2 & Bell Family Nursery \\
\hline H. anomala ssp. petiolaris 'Mirranda' & MAST (3005) \\
\hline H. anomala ssp. petiolaris group quelpartensis $1^{\mathrm{y}}$ & S. Reed (G436A) \\
\hline H. anomala ssp. petiolaris group quelpartensis 2 & Bell Family Nursery \\
\hline Platycrater arguta $\mathrm{Z}$ & S. Reed $(\mathrm{G} 718 \mathrm{~B})$ \\
\hline H. scandens ssp. chinensis group angustipetala 1 & MAST (2905) \\
\hline H. scandens ssp. chinensis group angustipetala 2 & S. Reed (G627A) \\
\hline H. scandens ssp. chinensis group lobbii & S. Reed (G520E) \\
\hline H. scandens ssp. liukiuensis group luteovenosa $1^{\mathrm{y}}$ & MAST (46300) \\
\hline H. scandens ssp. liukiuensis group luteovenosa 2 & S. Reed (G525D) \\
\hline H. scandens ssp. liukiuensis group luteovenosa 'Aureomarginata' & MAST (38998) \\
\hline Schizophragma hydrangeoides ${ }^{\mathrm{y}}$ & Bell Family Nursery \\
\hline Schizophragma hydrangeoides 'Moonlight' & S. Reed (G719B) \\
\hline H. heteromalla 1 & S. Reed (G432A) \\
\hline H. heteromalla 2 & S. Reed (G639A) \\
\hline H. heteromalla 3 & S. Reed (G640A) \\
\hline H. heteromalla group xanthoneura & S. Reed (G644A) \\
\hline H. paniculata 'Brussel's Lace' & Bell Family Nursery \\
\hline H. paniculata 'Greenspire' & MAST (65001) \\
\hline H. paniculata 'Limelight' & S. Reed (G582C) \\
\hline H. paniculata 'Pee Wee' & S. Reed (G652A) \\
\hline H. paniculata 'Pink Diamond' & S. Reed (G653B) \\
\hline H. paniculata 'Tardiva' & S. Reed (G654A) \\
\hline H. macrophylla 'Alpengluhen' & MAST (43200) \\
\hline H. macrophylla 'Ayesha' & Bell Family Nursery \\
\hline H. macrophylla 'Blaumeise' & S. Reed (G598A) \\
\hline H. macrophylla 'DavidRamsey' & MAST (37902) \\
\hline H. macrophylla 'Dooley' & Bell Family Nursery \\
\hline H. macrophylla 'Eisvogel' & S. Reed (G884) \\
\hline H. macrophylla Endless Summer ('Bailmer') & Bell Family Nursery \\
\hline H. macrophylla 'Holstein' & S. Reed (G344B) \\
\hline H. macrophylla 'Izu No Hana' & MAST (44800) \\
\hline
\end{tabular}

continued next page
ABI3730xl using ROX-500 size standard (Applied Biosystems, Foster City, Calif.). GeneMapper version 3.7 was used to recognize and size peaks (Applied Biosystems).

DAta ANAlysis. Data from 14 SRR loci were compiled for 85 samples and analyzed for shared allele frequencies. Among population variation was calculated for each subsection and species by comparing effective numbers of alleles to differences in allele frequencies between taxa. Assignment tests were not carried out since populations were based on subsection and species designations. Gene diversity estimates were produced using Nei's 1987 estimator for heterozygosity and unbiased gene diversity per populations using FSTATS software (Goudet, 1995; Saitou and Nei, 1987). Allele sharing statistics were used independent of ploidy differences and all alleles were represented as diploid. Average gene diversity was calculated between populations (Dst) and calculated relative to total gene diversity (Gst) (Nei, 1973).

Populations version 1.2.28 was used for phenetic analyses (Langella, 2002). Genetic distances between individual samples were calculated using allele sharing distance (DAS) to create a distance matrix (Jin and Chakraborty, 1994; Stephens et al., 1992). Neighbor-joining with 100 bootstrap replicates for statistical support was used to generate tree phenograms showing clustering of genetically similar samples (Saitou and Nei, 1987). Phenograms were visualized with TreeView (Page, 1996).

\section{Results}

Marked species listed in Table 1 were processed with SSR primers described in Table 2. Nine of the 14 SSR loci share sequence similarity with known genes and proteins. All repeats are trinucleotide and all but three loci produced a range of actual allele sizes that included the predicted size. The number of alleles varied from 4 to 17 . A complete list of the samples and their origin is shown in Table 3. Seven of the 85 samples failed to generate data with all 14 SSR primers (Table 3). Schizophragma hydrangeoides Sieb. and Zucc. is missing data for four loci, S. hydrangeoides 'Moonlight' for two loci and $P$. arguta for three loci. Individual samples for $H$. anomala D. Don, H. scandens (L.)Ser., and $H$. macrophylla ssp. serrata are missing data, but in these cases there are additional samples for each taxa that produced data for all 14 SSR loci. 
Table 3. Continued.

\begin{tabular}{|c|c|}
\hline Taxa & Source $^{\mathrm{z}}$ (accession no.) \\
\hline H. macrophylla 'Jogasaki' & MAST (47600) \\
\hline H. macrophylla 'Kardinal' & S. Reed (G597B) \\
\hline H. macrophylla 'Lemon Wave' & Bell Family Nursery \\
\hline H. macrophylla 'Libelle White' & MAST (46400) \\
\hline H. macrophylla 'Mariesii' & MAST (43101) \\
\hline H. macrophylla 'Nightingale' & MAST (46500) \\
\hline H. macrophylla 'Nigra' & S. Reed (G456B) \\
\hline H. macrophylla 'Nikko Blue' & S. Reed (G596B) \\
\hline H. macrophylla 'Penny Mac' & S. Reed (G683B) \\
\hline H. macrophylla 'Pia' & Bell Family Nursery \\
\hline H. macrophylla 'Seafoam' & Bell Family Nursery \\
\hline H. macrophylla 'Veitchii' & Bell Family Nursery \\
\hline Dichroa febrifuga & S. Reed (G717C) \\
\hline Dichroa febrifuga 'Yamaguchi Select' & MAST (27004) \\
\hline Dichroa versicolor 'Hogan' & MAST (43402) \\
\hline H. macrophylla ssp. serrata 'Beni Gaku' & Bell Family Nursery \\
\hline H. macrophylla ssp. serrata 'Bluebird' & $\operatorname{MAST}(26500)$ \\
\hline H. macrophylla ssp. serrata group fertilis & MAST (8102) \\
\hline H. macrophylla ssp. serrata group forma chinensis ${ }^{\mathrm{y}}$ & MAST (49700) \\
\hline H. macrophylla ssp. serrata 'Miranda' & MAST (46900) \\
\hline H. macrophylla ssp. serrata 'Omacha' & Bell Family Nursery \\
\hline H. macrophylla ssp. serrata 'Shichidanka' & S. Reed (G705D) \\
\hline H. macrophylla ssp. serrata 'Tiara' & MAST (47400) \\
\hline H. macrophylla ssp. serrata 'Woodlander' & MAST (75299) \\
\hline H. macrophylla ssp. serrata 'Yae No Amacha' & MAST (47500) \\
\hline H. seemannii 1 & S. Reed (G434A) \\
\hline H. seemannii 2 & Bell Family Nursery \\
\hline H. integrifolia & S. Reed (G633A) \\
\hline H. serratifolia & S. Reed (G567B) \\
\hline
\end{tabular}

$\overline{{ }^{\mathrm{z}} \text { Bell Family Nursery = Bell Family Nursery, Inc., Aurora, Ore.; M. Dirr = M.A. Dirr, Shade Garden }}$ Hydrangea Collection, University of Georgia, Athens; MAST =MAST Arboretum, Steven F. Austin State Univ., Nacogdoches, Texas; S. Reed = S.M. Reed, USDA-ARS, McMinnville, Tenn.

${ }^{y}$ Indicates samples that failed to generate data for one or more of the 14 SSR loci tested.

locus and the mean for all loci is 0.735 while the average gene diversity (Hs) for each locus is 0.370 (Table 4). If samples were randomly chosen from subsections they should differ on average at $37 \%$ of their loci. If they are chosen from the whole sample the difference increases to $73.5 \%$. Dst and Gst values are 0.366 and 0.497 , respectively. Thus, $49.7 \%$ of the overall variation is due to differences between subsections and diversity among subsections was $36.6 \%$. Gene diversity measures were also calculated for populations defined by species labels (data not shown). When analyzed by species, Dst and Gst values are higher at 0.454 and 0.617 , respectively. In other words, $61.7 \%$ of the total diversity is due to differences between species.

Genetic distance measures for each subsection ranged from 0.328 between Calyptranthae (Maxim.) E.M. McClint. and Asperae, indicating greater genetic similarity between these subsections, to 0.901 between Macrophyllae and section Cornidia, suggesting significant genetic divergence between these taxa (Table 5). Samples in subsection Macrophyllae appear genetically similar to Petalanthe and both subsections cluster separately from other taxa (Fig. 2).

Most of the associations between subsections remain intact when samples are analyzed at the species level. Data include Platycrater, Schizophragma, and Dichroa genera. Figure 3 shows $H$.

Measures of genetic diversity varied considerably between loci. Heterozygosity (Ho) using Nei's (1987) estimation indicated that the STAB111_112 locus generated the most variation while STAB457_458 locus had the least (Table 4). STAB061_062, STAB125_126,STAB307_308, and STAB309_310 also had low genetic diversity indicating low numbers of polymorphic alleles for these loci (Table 4). The most diverse loci were STAB111_ 112 and STAB285_286 with the next most diverse locus being STAB311_312 with $10 \%$ less polymorphic alleles. The range of heterozygosity suggests that these SSR are appropriate for the subsection and species level comparisons.

Number of alleles per locus was calculated for all samples and for each subsection individually. As expected,STAB457_458 had the most fixed loci with six and the least number of total alleles (Table 4). Loci with low genetic diversity generally had fewer alleles and more allele fixation. However, higher genetic diversity did not necessarily mean more alleles since STAB311_312 had the most alleles at 17, including one fixed for Macrophyllae, but had less observed heterozygosity, or genetic diversity, than STAB111_112 and STAB285_286. Four loci did not produce fixed alleles for any subsection, but each subsection included at least three fixed loci. Data for Dichroa, Platycrater, and Schizophragma samples were not included in subsection analyses since their placement in the tribe has not been established.

Diversity within and between populations was calculated several ways. Total gene diversity $(\mathrm{Ht})$ was calculated for each macrophylla ssp. macrophylla and H. macrophylla ssp. serrata are genetically similar to each other and to Dichroa and $H$. scandens. All four species are removed from other taxa (Fig. $3,88 \%$ bootstrap support). Hydrangea heteromalla D. Don and H. paniculata of subsection Heteromallae cluster with $100 \%$ bootstrap. Schizophragma shares considerable genetic similarity with $H$. heteromalla and $H$. paniculata. Species did not always associate within their subsection. For example, $H$. involucrata and $H$. aspera of subsection Asperae are only associated with minimal bootstrap support and $H$. involucrata appears more closely related to $H$. anomala of subsection Calyptranthae than to $H$. aspera (54\% bootstrap support). Platycrater shares genetic similarity with species in section Cornidia but bootstrap support is low at $71 \%$ (Fig. 3).

Genetic similarity between individual samples is shown in Fig. 4, which is rooted with S. hydrangeoides since SSR loci used here did not amplify with other outgroups. All samples cluster by species except for $H$. macrophylla cultivars Pia, Kardinal, and Veitchii, which share genetic similarity with $H$. macrophylla ssp. serrata. Grouping between samples is generally consistent with subsection- and species-level results shown in Figs. 2 and 3. Hydrangea paniculata and $H$. heteromalla cluster together with $87 \%$ bootstrap support and share genetic similarity with Schizophragma samples. As expected, Dichroa, H. scandens, and $H$. macrophylla cluster separate from other taxa. On the other hand, $H$. arborescens and $H$. quercifolia are genetically similar 
Table 4. Gene diversity and number of alleles per locus for entire population and within Hydrangea subsections. Data does not include Dichroa, Platycrater, and Schizophragma plants. Zero values for gene diversity within subsections indicate homozygous, fixed loci within that subsection.

\begin{tabular}{|c|c|c|c|c|c|c|c|c|c|c|c|c|c|}
\hline \multirow[b]{2}{*}{ Locus } & \multicolumn{2}{|c|}{ Genetic diversity } & \multicolumn{11}{|c|}{ Gene diversity within subsections (alleles per locus) } \\
\hline & $\mathrm{Ho}^{2}$ & (no.) & $\mathrm{Ht}^{\mathrm{y}}$ & $\mathrm{Hs}^{\mathrm{x}}$ & Dst $^{\mathrm{w}}$ & $\mathrm{Gst}^{\mathrm{v}}$ & Macrophyllae & Petalanthe & Heteromallae & Americanae & Cornidia & Calyptranthae & Asperae \\
\hline STAB045_046 & 0.43914 & 10 & 0.651 & 0.018 & 0.633 & 0.972 & $0.742(6)$ & $0.783(4)$ & $0.361(4)$ & $0.455(4)$ & $0.667(2)$ & $0.500(2)$ & $0.753(5)$ \\
\hline STAB061_062 & 0.03325 & 6 & 0.584 & 0.033 & 0.551 & 0.943 & $0.151(2)$ & $0.000(1)$ & $0.000(1)$ & $0.000(1)$ & $0.000(1)$ & $0.000(1)$ & $0.071(2)$ \\
\hline STAB111_112 & 0.76267 & 12 & 0.898 & 0.618 & 0.28 & 0.312 & $0.737(6)$ & $0.433(3)$ & $0.500(2)$ & $0.768(4)$ & $0.792(4)$ & $0.500(2)$ & $0.604(4)$ \\
\hline STAB125_126 & 0.09568 & 9 & 0.72 & 0.323 & 0.398 & 0.552 & $0.543(5)$ & $0.300(2)$ & $0.533(2)$ & $0.536(2)$ & $0.000(1)$ & $0.000(1)$ & $0.258(2)$ \\
\hline STAB157_158 & 0.34388 & 11 & 0.853 & 0.516 & 0.337 & 0.395 & $0.000(1)$ & $0.833(5)$ & $0.756(4)$ & $0.688(3)$ & $0.000(1)$ & $0.450(2)$ & $0.846(7)$ \\
\hline STAB285_286 & 0.71626 & 10 & 0.789 & 0.532 & 0.258 & 0.327 & $0.494(2)$ & $0.583(3)$ & $0.783(5)$ & $0.518(2)$ & $0.250(2)$ & $0.500(2)$ & $0.571(3)$ \\
\hline STAB307_308 & 0.09491 & 9 & 0.588 & 0.193 & 0.395 & 0.672 & $0.491(5)$ & $0.167(2)$ & $0.000(1)$ & $0.000(1)$ & $0.000(1)$ & $0.000(1)$ & $0.618(4)$ \\
\hline STAB309_310 & 0.07558 & 8 & 0.767 & 0.349 & 0.418 & 0.545 & $0.359(2)$ & $0.000(1)$ & $0.689(3)$ & $0.750(3)$ & $0.667(2)$ & $0.000(1)$ & $0.000(1)$ \\
\hline STAB311_312 & 0.60918 & 17 & 0.879 & 0.577 & 0.301 & 0.343 & $0.000(1)$ & $0.500(3)$ & $0.906(11)$ & $0.750(4)$ & $0.833(5)$ & $0.350(2)$ & $0.712(4)$ \\
\hline STAB321_322 & 0.16820 & 9 & 0.483 & 0.17 & 0.313 & 0.648 & $0.746(6)$ & $0.000(1)$ & $0.000(1)$ & $0.393(2)$ & $0.000(1)$ & $0.000(1)$ & $0.000(1)$ \\
\hline STAB391_392 & 0.28840 & 7 & 0.662 & 0.302 & 0.36 & 0.544 & $0.532(3)$ & $0.500(2)$ & $0.000(1)$ & $0.598(4)$ & $0.000(1)$ & $0.000(1)$ & $0.440(2)$ \\
\hline STAB429_430 & 0.47132 & 8 & 0.769 & 0.358 & 0.411 & 0.534 & $0.567(4)$ & $0.300(2)$ & $0.189(2)$ & $0.000(1)$ & $0.500(2)$ & $0.450(2)$ & $0.467(2)$ \\
\hline STAB457_458 & 0.01786 & 4 & 0.791 & 0.608 & 0.182 & 0.231 & $0.000(1)$ & $0.000(1)$ & $0.000(1)$ & $0.125(2)$ & $0.000(1)$ & $0.000(1)$ & $0.000(1)$ \\
\hline STAB501_502 & 0.51343 & 13 & 0.859 & 0.578 & 0.281 & 0.327 & $0.567(5)$ & $0.700(3)$ & $0.194(3)$ & $0.536(2)$ & $0.833(4)$ & $0.500(2)$ & $0.687(4)$ \\
\hline Mean & & & 0.735 & 0.370 & 0.366 & 0.497 & & & & & & & \\
\hline
\end{tabular}

${ }^{\mathrm{z}} \mathrm{Ho}=$ observed heterozygosity, or genetic diversity, for all samples.

${ }^{\mathrm{y}} \mathrm{Ht}=$ total gene diversity.

${ }^{\mathrm{x}} \mathrm{Hs}=$ average gene diversity within subsections.

${ }^{\mathrm{w}}$ Dst $=$ average gene diversity between subsections.

${ }^{\mathrm{v}} \mathrm{Gst}=$ genetic differentiation between subsections.

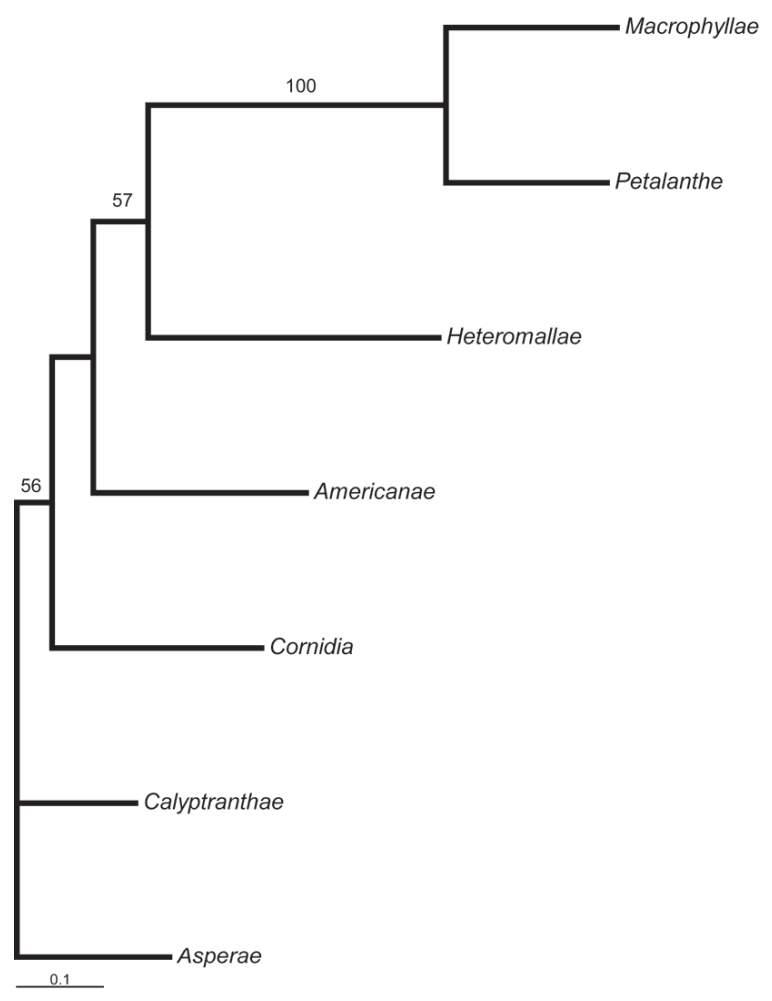

Fig. 2. This unrooted, neighbor-joining tree is based on allele sharing distances calculated for populations and indicates relationships, or clusters, between subsections. Data did not include Dichroa, Platycrater, and Schizophragma genera. Numbers correspond to 100 bootstrap replicates where higher numbers indicate increased statistical support. Bootstrap values less than 50 are not shown.

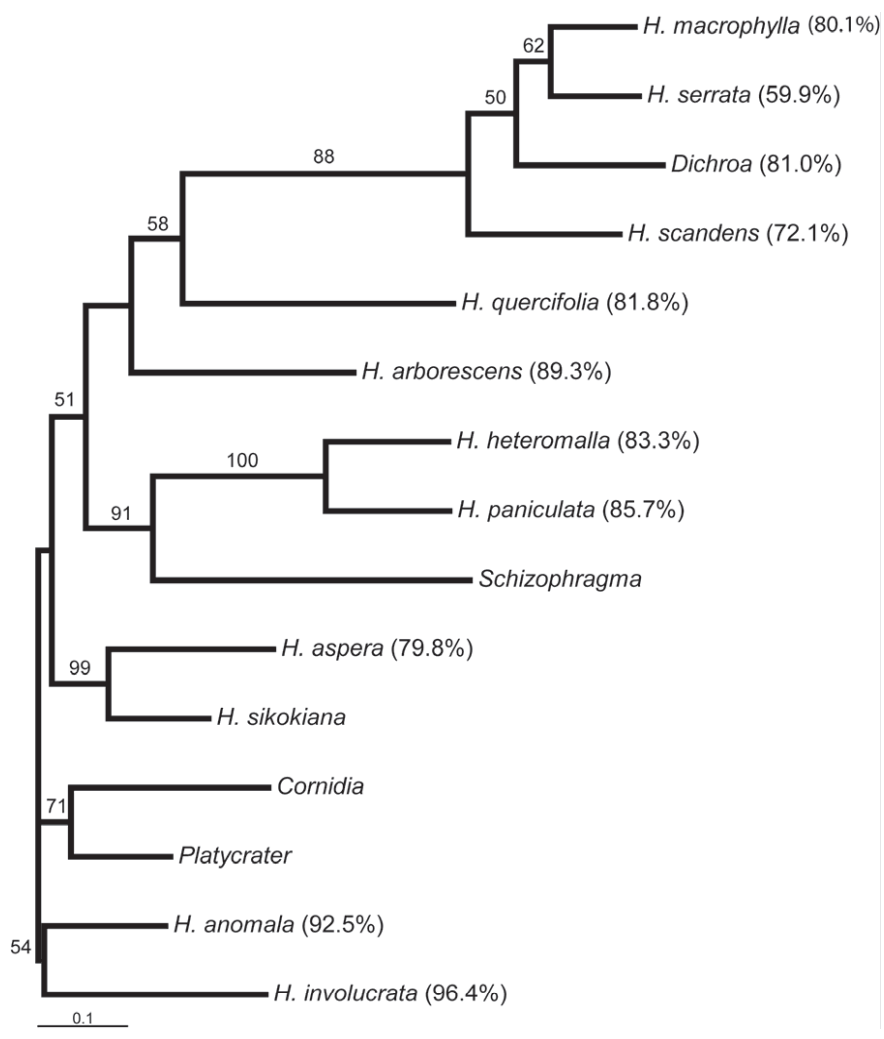

Fig. 3. Neighbor-joining tree was created using allele sharing distance and analysis of populations based on species groups. 100 bootstrap replicates were used for statistical support and percentages are shown above branches. Average genetic similarity within each species is shown next to each species except for species only represented by two or less samples. Bootstrap values less than 50 are not shown. 
Table 5. Allele sharing distances between Hydrangea subsections. Higher values indicate greater genetic distance between taxa and lower values suggest increased genetic similarity. Data for Dichroa, Platycrater, and Schizophragma samples were not included since their placement within Hydrangea subsections is not well defined.

\begin{tabular}{lccccccc}
\hline & Macrophyllae & Petalanthe & Heteromallae & Americanae & Cornidia & Calyptranthae & Asperae \\
\hline Macrophyllae & 0 & & & & & & \\
Petalanthe & 0.384950 & 0 & & & & & \\
Heteromallae & 0.887048 & 0.862039 & 0 & & & \\
Americanae & 0.802261 & 0.800027 & 0.694377 & 0 & & \\
Cornidia & 0.901107 & 0.881984 & 0.683460 & 0.540729 & 0 & 0.328404 \\
Calyptranthae & 0.862428 & 0.855892 & 0.636332 & 0.473218 & 0.41499 & 0 \\
Asperae & 0.886986 & 0.885090 & 0.627525 & 0.519281 & 0.483813 & 0.328 \\
\hline
\end{tabular}

but are included in a large group that includes section Cornidia and subsection Asperae samples. Genetic similarity between species is relatively uninformative when compared to Fig. 3. For example, $P$. arguta and $H$. sikokiana appear genetically similar to H. anomala instead of H. aspera and Section Cornidia.

Associations between subspecies and individual samples are better supported by bootstrap analysis in Fig. 4. Hydrangea macrophylla cultivars Dooley, Nikko Blue, Penny Mac, David Ramsey, and Bailmer (Endless Summer) are remontant and were previously described using RAPD markers (Lindstrom et al., 2003). Their genetic similarity is confirmed here (Fig. 4, 82\% and $81 \%$ bootstrap support). Hydrangea scandens ssp. chinensis (Maxim.) E.M. McClint. and H. scandens ssp. liukiuensis (Nakai) E.M. McClint. cluster separately. Hydrangea anomala D. Don ssp. petiolaris (Sieb. and Zucc) E.M. McClint. samples that were sold under the name "H. quelpartensis" appear genetically distinct from other H. anomala ssp. petiolaris samples. Hydrangea aspera ssp. aspera, H. aspera ssp. strigosa (Rehder) E.M. McClint., and $H$. aspera ssp. villosa Rehder form a separate genetic group from $H$. aspera ssp. sargentiana and $H$. aspera ssp. robusta (Fig. 4, $62 \%$ bootstrap support).

A dichotomous molecular key based on SSR allele size was developed for the 17 species analyzed using 14 SSR loci (Fig. 5 ). Highly polymorphic alleles in combination with fixed, homozygous loci within each subsection make species identification possible using as few as two SSR loci depending on the sample. For example, $H$. scandens ssp. liukiuensis can be identified by unique alleles for loci STAB61_62 and STAB157_158 (Fig. 5 ). Other species and subspecies require more loci, but the full panel of $14 \mathrm{SSR}$ is sufficient to resolve all species tested. The single exception in our data is the closely related $H$. macrophylla ssp. macrophylla and $H$. macrophylla ssp. serrata designations, which are not unambiguously identified with the SSR markers analyzed here.

\section{Discussion}

SSR loci were chosen specifically for their ability to amplify across species and their polymorphic content. Null alleles were considered missing data which reduced the resolving power of our data but did not change the overall genetic comparisons between samples and species. Missing data were not confined to a particular locus, but Platycrater and Schizophragma samples failed to generate data for more loci than other samples. This might reflect their genetic divergence from $H$. macrophylla and $H$. paniculata, the DNAs used to construct the SSR-enriched library. Nine of the microsatellite regions share sequence similarity with known genes. Several are genes coding for conserved plant functions which is expected since these loci amplify in 17 different species (Rossetto, 2001).
We tested several genetic distance methods including stepwise mutation models for SSR evolution such as ASD, $\mathrm{D}_{\mathrm{sw}}$, and DMU2 (Goldstein and Clark, 1995; Goldstein and Pollock, 1997; Pollock et al., 1998; Shriver et al., 1995). Empirical testing of the step-wise mutation models resulted in unstable phylogenies, probably because our SSR loci are highly polymorphic and allele sizes varied greatly (Table 2). We did not sequence repeats in all species to confirm that allele size variation only represents differences in repeat number and does not include additional mutations and imperfections. Proper use of step-wise mutation models would require that we constrain allele size ranges and estimate mutation rates. The underlying purpose of this work was to enhance hydrangea breeding by establishing a molecular key for Hydrangea species which is better accomplished when the allele size range is not constrained. Accordingly, most of our samples are named cultivars and do not necessarily represent genetic diversity found in wild populations. Samples were duplicated and intentionally collected from multiple sources to better protect against mislabeled plants (Table 3 ). However, sampling methods did not guard against the bias of cultivated plants, which may be derived from a single genetic source. Regardless, the results presented here are valuable to hydrangea breeding programs, which look to maximize genetic diversity and typically utilize named cultivars with proven ornamental traits.

According to our data, McClintock correctly removed Macrophyllae from Petalanthe and made it a separate subsection since the species in each subsection appear genetically distinct from each other (Figs. 2 and 3). Our results also support McClintock's assertion that serrata is a subspecies of H. macrophylla (Fig. 4). Hydrangea macrophylla ssp. macrophylla and H. macrophylla ssp. serrata are $80 \%$ similar but the average genetic similarity within $H$. macrophylla ssp. serrata is $60 \%$, which is the least amount of genetic similarity for any species tested (Table 6 and Fig. 3). Genetic similarity within H. macrophylla ssp. macrophylla is $80 \%$, which is within the range of similarity for most species tested (Fig. 3, 72\% to 96\%). Despite low genetic similarity within $H$. macrophylla ssp. serrata, genetic similarity between $H$. macrophylla ssp. serrata and other species is comparable to that between $H$. macrophylla ssp. macrophylla and those species, which is consistent with a subspecies designation (Table 6). Subspecies designations could be tested via fertility analysis and hybrid production.

Hydrangea macrophylla ssp. macrophylla cultivars Veitchii, Pia, and Kardinal appear more genetically similar to H. macrophylla ssp. serrata than to other H. macrophylla ssp. macrophylla cultivars (Fig. 6). Their placement between subspecies groups suggests that they may be hybrids. The hybrid nature of a few $H$. macrophylla ssp. serrata cultivars was proposed by Zonneveld (2004) after uncovering genome sizes that were intermediate 


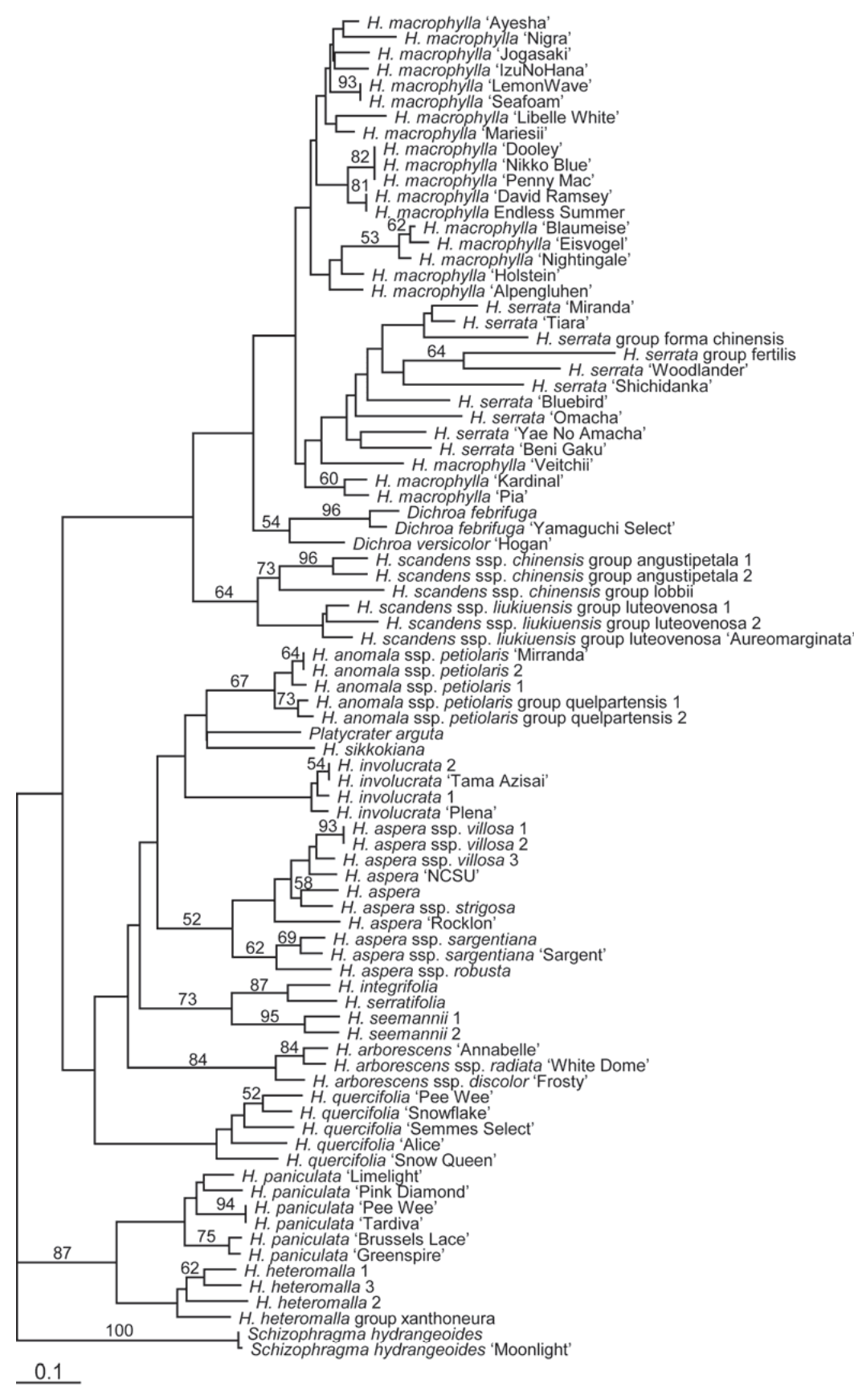

Fig. 4. This neighbor-joined tree includes all individual data used in our analysis and is rooted with Schizophragma samples. Numbers correspond to 100 bootstrap replicates where higher numbers indicate more statistical support. Bootstrap values less than 50 are not shown.

between $H$. macrophylla ssp. serrata and H. macrophylla ssp. macrophylla, which the author suggests are two separate species. The detection of probable hybrids, a lack of unique SSR alleles in our molecular key, and the close genetic distance support the subspecies designations introduced by McClintock (1957).

Several known links within H. macrophylla ssp. macrophylla cultivars are confirmed by our analyses. 'Dooley', 'Nikko Blue', 'David Ramsey', and 'Endless Summer' share remontant flowering traits and the SSR-derived phylogeny matches previous RAPD analysis results (Adkins and Dirr, 2003; Lindstrom et al., 2003). 'Seafoam' and 'Lemon Wave' are both variegated and appear joined with $93 \%$ bootstrap support (Fig. 6). 'Blaumeise', 'Eisvogel', and 'Nachtigall' are known triploids (Zonneveld,
2004) produced by the same breeding program and cluster with $53 \%$ bootstrap support. A more detailed study of $H$. macrophylla ssp. macrophylla and $H$. macrophylla ssp. serrata is under way with a larger pool of SSR markers.

Macrophyllae and Petalanthe appear to be more closely related to each other than to the rest of the Hydrangea species (Table 5; Figs. 2 and 3). This divergence is consistent with the consensus tree for Hydrangea in Fig. 1 but has consequences for Hydrangea breeding since the most popular and colorful hydrangeas are H. macrophylla cultivars. Introgressing flower color and other ornamental traits through interspecific breeding has proven to be difficult (Kudo and Niimi, 1999; Reed, 2000, 2004; Reed et al., 2001). According to SSR data, the exceptions should be H. scandens and Dichroa species which are tightly grouped with $H$. macrophylla (Fig. 5) and share a considerable number of alleles (Table 6). The relatively high coefficient of differentiation (Gst) suggest geographic or ecological isolation of the subsections (Table 4). Within and between subspecies diversity, Hs and Dst, were approximately equal and genetic similarity clustering shows clear distinction between subsections. Results for species indicate that the average gene diversity within species was lower (0.282) and the average diversity between species was higher (0.454). The resulting higher Gst value (0.617) suggests that more of the total diversity is due to differentiation between species. These statistics should be regarded as a convenient summary since there are a relatively small number of loci involved and diversity and distance for the entire genome would require more loci. Comparable results between subsection and species-level analyses is most likely due to the fact that the seven subsections are only subdivided into 11 species groups with three of the groups retaining the same samples.

Genetic distance alone is a poor indicator of compatibility since Dichroafebrifuga Lour. is potentially a hexaploid (K. Jones, personal communication). Genome size and chromosome counts are not yet available for Dichroa versicolor (Fortune) D.R. Hunt. Fertility needs to be empirically tested but if wide hybrids can be made, they can be rapidly and inexpensively verified using the SSR markers described here.

Hydrangea anomala samples appear to segregate into two groups based on origin (Fig. 4). Hydrangea anomala ssp. petiolaris is generally collected from Japan while samples labeled "H.quelpartensis" are associated with wild populations in South Korea. Both are aerial-rooting climbing plants with white lacecap flowers. Likewise, $H$. scandens ssp. chinensis and $H$. scandens ssp. liukiuensis form separate groups with reasonable bootstrap support (Fig. 4). Hydrangea scandens ssp. chinesis is sold as "H. angustipetala" and $H$. scandens ssp. liukiuensis is sold as "H. luteovenosa." They are extant to Taiwan and the mountains of Japan, respectively. Hydrangea scandens ssp. chinesis group angustipetala are deciduous while $H$. scandens ssp. liukiuensis group luteovenosa plants are generally semi-evergreen. Interestingly, H. scandens ssp. chinesis, also sold as "H. lobbii," is found 


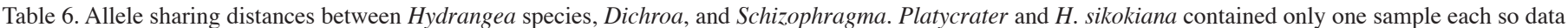
were not included. Hydrangea macrophylla samples were divided into macrophylla and serrata subspecies. Section Cornidia contains data for H. seemannii, H. integrifolia, and H. serratifolia. Taxa labels are abbreviated on the upper axis to maintain spacing within columns.

\begin{tabular}{|c|c|c|c|c|c|c|c|c|c|c|c|c|c|}
\hline & mac. & serrata & Dichroa & scanden & hetero. & panicul. & Schizo. & arbores. & quercif. & Cornidia & anomala & aspera & Involucr. \\
\hline $\begin{array}{l}\text { H. macrophylla } \\
\text { ssp. macrophylla }\end{array}$ & 0 & & & & & & & & & & & & \\
\hline H. macrophylla & & & & & & & & & & & & & \\
\hline ssp. serrata & 0.193389 & 0 & & & & & & & & & & & \\
\hline Dichroa & 0.249481 & 0.350568 & 0 & & & & & & & & & & \\
\hline H. scandens & 0.421015 & 0.385957 & 0.343507 & 0 & & & & & & & & & \\
\hline H. heteromalla & 0.895931 & 0.867574 & 0.952899 & 0.860489 & 0 & & & & & & & & \\
\hline H. paniculata & 0.899819 & 0.929760 & 0.907143 & 0.881215 & 0.276408 & 0 & & & & & & & \\
\hline Schizophragma & 0.895772 & 0.916559 & 0.966228 & 0.888415 & 0.737500 & 0.638034 & 0 & & & & & & \\
\hline H. arborescens & 0.858754 & 0.918000 & 0.878788 & 0.908059 & 0.806897 & 0.755102 & 0.806289 & 0 & & & & & \\
\hline H. quercifolia & 0.824333 & 0.801392 & 0.865399 & 0.782513 & 0.697188 & 0.786780 & 0.889064 & 0.529576 & 0 & & & & \\
\hline Cornidia & 0.906067 & 0.903134 & 0.961538 & 0.881984 & 0.704545 & 0.710821 & 0.713527 & 0.540146 & 0.655700 & 0 & & & \\
\hline H. anomala & 0.868175 & 0.837373 & 0.904551 & 0.843299 & 0.657337 & 0.632964 & 0.606963 & 0.417587 & 0.629303 & 0.363454 & 0 & & \\
\hline H. aspera & 0.908121 & 0.917714 & 0.940770 & 0.894446 & 0.717656 & 0.755513 & 0.620499 & 0.622712 & 0.643801 & 0.567665 & 0.372634 & 0 & \\
\hline H. involucrata & 0.897871 & 0.891669 & 0.932886 & 0.914130 & 0.587748 & 0.627451 & 0.813333 & 0.592949 & 0.727455 & 0.517483 & 0.355913 & 0.542098 & 0 \\
\hline
\end{tabular}

in the Philippines and Taiwan and listed as semi-evergreen. SSR data suggest $H$. scandens ssp. chinesis group lobbii may be a hybrid between $H$. scandens subspecies but only one sample has been tested.

Five $H$. aspera subspecies were included in our data and results indicate $H$. aspera ssp. aspera, $H$. aspera ssp. strigosa, and $H$. aspera ssp. villosa form a separate group from $H$. aspera ssp. sargentiana and H. aspera ssp. robusta (Fig. 4). Hydrangea aspera occur in China, mainly in the Himalaya Mountains, but also in western and south central regions, and on the islands of Formosa, Sumatra, and Java (McClintock, 1957). No particular geographic or morphological information is consistent with the groups shown in Fig. 4 and the within species genetic similarity is comparable to other species (Fig. 3). Greater genetic diversity was expected because previous reports of geographic range, genome size ranges, and morphological variation indicated higher levels than other Hydrangea species (Table 1) (Hutchinson, 1967; Soltis et al., 1995; Zonneveld, 2004). Several cultivars are available and plants such as 'Sargent' have desirable traits including large fuzzy leaves and deep purple flowers suggesting further genetic testing is warranted. Sample clustering within H. aspera suggests genetic structure within species and genetic diversity could be maximized when breeding by selection of parents. Similar conclusions could be made for $H$. macrophylla, H. anomala, and $H$. paniculata (Fig. 4).

Despite the genetic similarity between H. aspera, H.anomala, H. involucrata, H. sikokiana, Platycrater, and Cornidia species, the relationships between these species, particularly the placement of $P$. arguta, is not well resolved. Bootstrap support at these nodes is low suggesting that Fig. 4 may not be accurate. Likewise, our SSR results do not contradict the consensus tree placement of $H$. quercifolia and $H$. arborescens, which are shown separate (Fig. 1). While a unified subsection Americanae is not necessarily ruled out, there is little support among the genetic data for a relationship such as that seen for $H$. heteromalla and $H$. paniculata of subsection Heteromallae (Figs. 3 and 4).

On the other hand, Schizophragma consistently appears joined to subsection Heteromallae including as much as $95 \%$ bootstrap support at the species level (Fig. 4). The Schizophragma clade in Fig. 1 contains Decumaria and Pileostegia, and is shown associated with $H$. quercifolia of subsection Americanae. Our results suggest the Schizophragma clade is genetically similar to subsection Heteromallae, although we cannot specifically address Decumaria and Pileostegia genera.
This work is the first comprehensive genetic analysis of species and subspecies relationships in Hydrangea. Although more samples would be needed to make firm conclusions about taxonomy, the SSR loci developed here are the first for Hydrangea and are sufficient to unambiguously determine species among the samples tested (Fig. 6). We hope the dichotomous molecular key is useful for verifying interspecific hybrids and for germplasm conservation efforts in this horticulturally important genus.

\section{Literature Cited}

Adkins, J.A. and M.A. Dirr. 2003. Remontant flowering potential of ten Hydrangea macrophylla (Thunb.) Ser. cultivars. HortScience 38:1337-1340.

Cerbah, M., E. Mortreau, S. Brown, S. Siljak-Yakovlev, H. Bertrand, and C. Lambert. 2001. Genome size variation and species relationships in the genus Hydrangea. Theor. Appl. Genet. 103(1):45-51.

Demilly, D., C. Lambert, and H. Bertrand. 2000. Diversity of nuclear DNA contents of Hydrangea. Acta Hort. 508:281-284.

Dirr, M.A. 2004. Hydrangeas for american gardens, Timber Press, Portland, Ore.

Fan, C. and Q.Y. Xiang. 2003. Phylogenetic analyses of Cornales based on 26S rRNA and combined 26S rDNA-matK-rbcL sequence data. Amer. J. Bot. 90(9):1357-1372.

Goldstein, D.B. and A.G. Clark. 1995. Microsatellite variation in North American populations of Drosophila melanogaster. Nucleic Acids Res. 23(19):3882-3886.

Goldstein, D.B. and D.D. Pollock. 1997. Launching microsatellites: A review of mutation processes and methods of phylogenetic inference. J. Hered. 88(5):335-342.

Goudet, J. 1995. FSTAT (version 1.2): A computer program to calculate F-statistics. J. Hered. 86:485-486.

Hara, H. 1955. Critical notes on some type specimens of east Asiatic plants in foreign herbaria. J. Jpn. Bot. 30:271-278.

Haworth-Booth, M. 1984. The hydrangeas. 5th ed. Constable, London.

Hufford, L. 1995. Seed morphology of Hydrangeaceae and its phylogenetic implications. Intl. J. Plant Sci. 156(4):555-580.

Hufford, L. 1997. A phylogenetic analysis of Hydrangeaceae based on morphological data. Intl. J. Plant Sci. 158(5):652-672.

Hufford, L. 2001. Ontogeny and morphology of the fertile flowers of Hydrangea and allied genera of tribe Hydrangeeae (Hydrangeaceae). Bot. J. Linnean Soc. 137(2):139-187.

Hufford, L., M.L. Moody, and D.E. Soltis. 2001. A phylogenetic analysis of Hydrangeaceae based on sequences of the plastid gene matK and their combination with rbcL and morphological data. Intl. J. Plant Sci. 162(4):835-846.

Hutchinson, J. 1967. The genera of flowering plants. Clarendon Press, Oxford, England. 


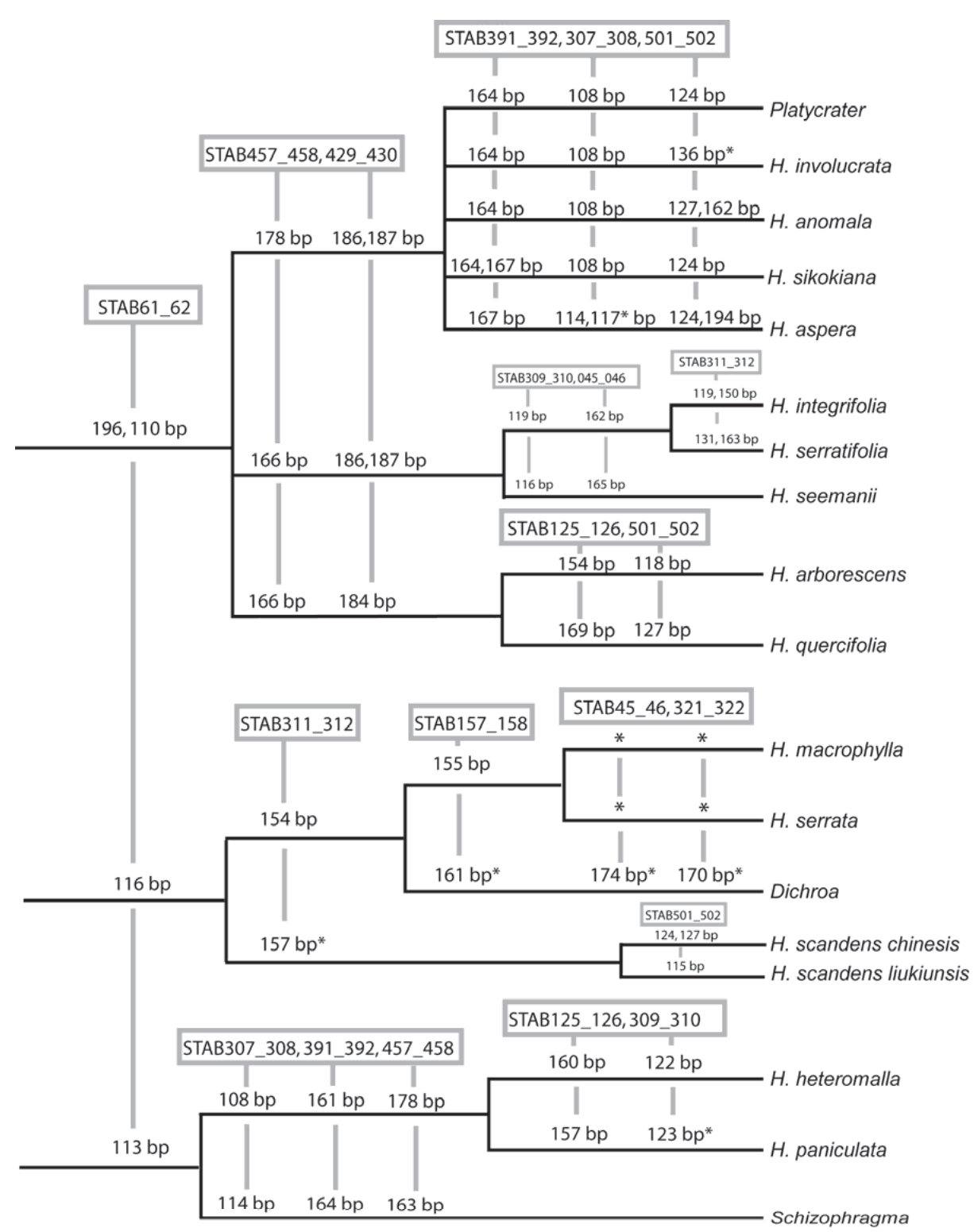

Fig. 5. Species and subspecies dichotomous key using 14 SSR markers is shown as a modified dendogram. SSR loci are named inside boxes above branches. Allele sizes are shown below each locus. Multiple alleles are listed for loci where both alleles are consistent and unique to that taxonomic group. Asterisks indicate loci where extra alleles were observed in addition to the unique sizes shown.

Jin, L. and R. Chakraborty. 1994. Estimation of genetic distance and coefficient of gene diversity from single-probe multilocus DNA fingerprinting data. Mol. Biol. Evol. 11:120-127.

Jones, K.D. and S.M. Reed. 2006. Production of Hydrangea arborescens 'Dardom' x H. involucrata hybrids. HortScience 41:564-566.

Kudo, N. and Y. Niimi. 1999. Production of interspecific hybrids between Hydrangea macrophylla f. Hortensia (Lam.) Rehd. and H. arborescens L. J. Jpn. Soc. Hort. Sci. 68(2):428-439.

Kudo, N., Y. Kimura, and Y. Niimi. 2002. Production of interspecific hybrid plants by crossing Hydrangea macrophylla f. Hortensia (Lam.) Rehd. and $H$. quercifolia Bartr. through ovule culture. Hort. Res. Jpn. 1:9-12.

Langella, O. 2002. Populations, A free population genetics software. 18 June 2006. <http://www.cnrs-gif.fr/pge/bioinfo/populations/index. php>.

Lawson-Hall, T. and B. Rothera. 1995. Hydrangeas, A gardeners guide. Timber Press, Portland, Ore.

Lindstrom, J.T., M.C. Pelto, and M.A. Dirr. 2003. Molecular assessment of remontant (reblooming) Hydrangea macrophylla cultivars. J. Environ. Hort. 21:57-60.

Mallet, C. 1994. Hydrangeas: Species and cultivars. Vol. 2. Centre d'Art Floral, Varengeville, France.

McClintock, E. 1957. A monograph of the genus Hydrangea. Proc. Calif. Acad. Sci. 29:147-256.

Nei, M. 1987. Molecular evolutionary genetics. Columbia University Press, New York.

Nei, M. 1973. Analysis of gene diversity in subdivided populations. Proc. Nat. Acad. Sci. USA 70(12):3321-3323.

Page, R.D. 1996. TreeView: An application to display phylogenetic trees on personal computers. Computer Appl. Biosci. 12(4):357-358.

Pollock, D.D., A. Bergman, M.W. Feldman, and D.B. Goldstein. 1998. Microsatellite behavior with range constraints: Parameter estimation and improved distances for use in phylogenetic reconstruction. Theoretical Population Biol. 53(3):256-271.

Reed, S. 2000. Compatibility studies in $H y$ drangea. J. Environ. Hort. 18(1):29-33.

Reed, S. 2004. Floral characteristics of a Hydrangea macrophylla $\times H$. paniculata hybrid. Proc. Southern Nursery Assn. Res. Conf. 49:580-582.

Reed, S., G.L. Riedel, and M.R. Pooler. 2001. Verification and establishment of Hydrangea macrophylla 'Kardinal' $x H$. paniculata 'Brussels Lace' interspecific hybrids. J. Environ. Hort. 19(2):85-88.

Rossetto, M. 2001. Sourcing of SSR markers from related plant species, p. 211-224. In R. J. Henry [ed.], Plant genotyping: The DNA fingerprinting of plants. CAB International, Wallingford, UK.

Saitou, N. and M. Nei. 1987. The neighborjoining method: A new method for reconstructing phylogenetic trees. Mol. Biol. Evol. 4(4):406-425.

Sax, K. 1931. Chromosome numbers in the ligneous Saxifragaceae. J Arnold Arboretum 12:198-205.

Shriver, M.D., L. Jin, E. Boerwinkle, R. Deka, R.E. Ferrell, and R. Chakraborty. 1995. A novel measure of genetic distance for highly polymorphic tandem repeat loci. Mol. Biol. Evol. 12(5):914-920.

Soltis, D.E., Q.Y. Xiang, and L. Hufford. 1995. Relationships and evolution of Hydrangeaceae based on rbcL sequence data. Amer. J. Bot. 82(4):504-514.

Stephens, J.C., D.A. Gilbert, N. Yuhki, and S. J. O'Brien. 1992. Estimation of heterozygosity for single-probe multilocus DNA fingerprints. Mol. Biol. Evol. 9(4):729-743.

van Gelderen, C.J. and D.M. van Gelderen. 2004. Encyclopedia of hydrangeas. Timber Press, Portland, Ore.

Waldbieser, G.C., S.M.A. Quiniou, and A. Karsi. 2003. Rapid development of gene-tagged microsatellite markers from bacterial artificial chromosome clones using anchored TAA repeat primers. BioTechniques 35(5):976-979.

Wilson, E.H. 1923. The hortensias: H. macrophylla Seringe and H. serrata (Thunberg) Seringe. J. Arnold Arboretum 4:233-246.

Zonneveld, B.J.M. 2004. Genome size in hydrangea, p. 245-255. In C.J. van Gelderen and D. M. van Gelderen (eds.), Encyclopedia of hydrangeas. Timber Press, Portland, Ore., USA. 